\title{
岩石の透水係数と試験中の供試体内 動水勾配の評価について
}

\author{
高橋 学* - 張 銘* = 林 為人** \\ 西山 哲***.李 小春**** \\ Experimental Study of Hydraulic Conductivity and Hydraulic Gradient \\ in Rock Specimen
Manabu TAKAHASHI*, Ming ZHANG*, Weiren LIN**, Satoshi NISHIYAMA***, Xiaochun LI****

\begin{abstract}
Laboratory measurement of the hydraulic conductivity of various rock types revealed that the hydraulic conductivity sensitively changes as the porosity and the stress state in the rock change. This effect becomes clear when the porosity and various principal stresses are increased. Review of the previous laboratory experiments indicate that the hydraulic conductivity of various rock types ranged between the order of $10^{-11} \mathrm{~cm} / \mathrm{sec}$ and $10^{\circ} \mathrm{cm} / \mathrm{sec}$, and it decreases as pore pressure decreases, confining pressure increases and intermediate principal stress increases.

The variation and distribution of hydraulic head and hydraulic gradient within a specimen were evaluated by a general equation which describes the transient pulse test. The hydraulic gradient during the early stage of the transient pulse test remarkably increased at around the upstream end of the specimen. As the time elapsed, the hydraulic head at the upstream side gradually decreased, whereas that at the downstream side monotonously and gradually increased.
\end{abstract}

Key words : Hydraulic conductivity, Porosity, Hydraulic gradient キーワード : 透水係数，間隙率，動水勾配

\section{I.はじめに}

ある媒体内の水の通り易さの指標として，“透 水係数”という概念が用いられている。工学から 理学, 医学に渡る広い分野で用いられているが, 同じ英語表現でありながらその訳が時として分野 毎に異なり，境界領域において他分野との共同研 究を行う際のささやかな混乱・障害となっている。 以下にその例を示す。
- permeability - 透水係数, 透過度, 透水度...

他（注1）

- permeability coefficient - 透水係数, 透水 度係数, 透過係数

- hydraulic conductivity - 透水係数, 水理 伝導率

これらは後述するダルシー則で定義される速度 $[\mathrm{cm} / \mathrm{sec}, \mathrm{m} / \mathrm{sec}]$ のディメンジョンを有する同 一のものである。一方, “intrinsic permeability”

*地質調查所環境地質部 (Geological Survey of Japan)

**(株ダイヤコンサルタント (Dia Consultants Co., Ltd.)

***(侏ジオジャイロ (Geogyro Co., Ltd.)

**** *茨城大学工学部 (Faculty of Engineering, Ibaraki University) 
は固有透水係数と呼ばれており, 流体の性質 $(\rho$, $\eta, \gamma$ 等) に依存しない量であり, 面積 $\left[\mathrm{cm}^{2}\right.$, $\mathrm{m}^{2}$ ] のディメンジョンを有するものである。

Darcy則は，『砂層を通り抜ける単位時間当た りの流量 $Q$ は断面積 $A$ および砂層の流入流出点 における流体の水頭差 $\Delta H$ に比例し, 砂層の厚 さLに反比例する』というものである。すなわ ち,

$$
Q=c A \Delta H / L
$$

と表される。cは砂層（あるいは砂）の特性を示 す定数である。透水係数 $K$ は(1)式のダルシー式 中の倸数 “ $c$ ”に相当し，多孔質媒質および流体 を含んだ複合媒質の有効透水係数の意味を持つこ とになる。

本文では文献から得られる岩石の透水係数の取 り得る範囲をおおよそ把握するため, 測定手法な どの詳細な情報にこだわらず整理してみた。その 後, コアサイズにおける透水係数測定結果として 主に主応力による影響量について概括する。最後 に，現状では岩石コア中の動水勾配を計測するこ とはできないので, 数值計算によって供試体中の 動水勾配分布を評価した事例について紹介する。

\section{II. 代表的な岩石の透水係数について}

日本における地下空間を利用する為の施工では, 地下水位の浅さ故に施工中はもとより, 施工後の 地下水流動を考慮しておく必要がある。各種地下 貯蔵施設等では, この地下水流動による有害污染 物質の拡散が重要なテーマとなっているのは一般 に知られているところである。この椂な地下地質 （土壤，岩盤を含めて）に扔ける地下水流動の基 本的な特性として“透水係数” (Hydraulic conductivity）があり，各種の原位置試験や室 内試験が提案・実用化されている。数 $\mathrm{cm}$ オーダー のコアサイズレベルにおける室内透水試験は, 原 位置の透水係数を得る代りの方法として，あるい は岩石中の物質移動の諸問題を解明するための基 礎物性試験として位置付けられてきた。原位置試 験における透水係数は, その地域, 地質, 深度,
目的等幅広い項目に依存するので，まとめるのが 容易ではない。一方, 室内試験における岩石を対 象とした透水試験は手法として限られている（定 水位及び変水位が主流, 他トランジェントパルス, フローポンプ, オシレーション試験) ので, 他の 基本物性との関連において整理する事ができる。

さて, 岩石の透水係数は当然のことながら, 岩 種に応じて異なる。これは基本的には岩石がどの ような鉱物から構成されているか, 空隙の寸法や 量, そして連結性などの種々の条件によって影響 されているからである。これらの諸条件の関連に ついては定性的には理解されているものの, その 複雑さ故に定量化されるにはいたっていない。こ こでは, 岩石の物性として一般的に測定され，基 本的に用いられている間隙率に着目し, 種々の岩 石における間隙率と透水係数との関連について整 理してみる。なお，各データに関して測定手法な どの差異については検討できないので, 測定手法 などの条件については無視して整理した。したがっ て，データの細部における議論は行わず，あくまで も定性的で一般的な内容にとどめておく。Fig. 1 は小鯛（1985）およびTouloukian et al. (1989) のデータをもとに, 各岩種毎に間隙率と透水係数 との関係を示したものである。間隙率の増加とと もに透水倸数は大きくなり，この傾向は岩種を問 わず当てはまる。一般的に物質内の水の流れは, ダルシー則にもあるように通路の断面積に比例し, 岩石の様な不均質な物質内では更に通路どうしの 連結性に大きく依存する。同一岩種の中でも産地 等の違いについては考慮されていないので, 透水 係数が間隙率に依存しない事を示すデー夕も散見 される。この場合には既述した様に，水の通路と なる空間部分の連結性の違いが大きく影響してい るものと思われる。これらのデータはナノダルシー $\left(\fallingdotseq 10^{-12} \mathrm{~cm} / \mathrm{sec}\right)$ の計測が可能な測定手法がほ とんど用いられていないなどの制約があるため, あたかも $10^{-11} \mathrm{~cm} / \mathrm{sec}$ 以下の岩石が存在しないか のように読み取れる。しかしながら，フローポンプ 法やトランジェントパルス法を用いると $10^{-12} \mathrm{~cm} /$ sec 領域の計測が可能となる。これらの詳細につ 


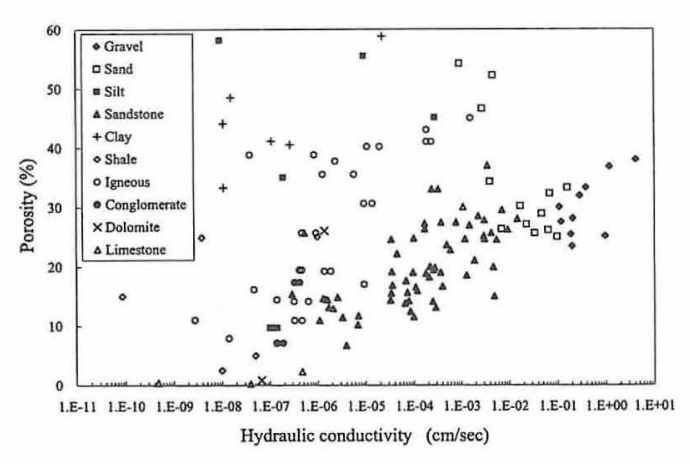

Fig. 1 The relationship between porosity and hydraulic conductivity of rocks

いては高橋ほか（1998）に述べられている。

柳澤ほか（1992）は地表から深度 $1000 \mathrm{~m}$ 付近ま での地盤における透水倸数の分布範囲を調べるた め，1980-1989年に発行された各種国内学術雑誌 をもとに文献調査を実施した。その結果, 日本の 地盤の透水係数は $10^{-8} \mathrm{~cm} / \mathrm{sec}$ か $10^{\circ} \mathrm{cm} / \mathrm{sec} に$ 分布していることなどを報告している。これらの データのうち, 間隙率が明確になっているものを 選び出し, 透水係数との関係を調べたのが, Fig. 2 である。岩種や測定手法など一切の属性を区分 することなく抽出したものであり, 間隙率との明 確な相関を見出すことができない。ここでは岩石 コアや原位置透水試験から得られる透水係数のお およその取り得る範囲を把握するために示した。 以下では, 実際に行われている測定結果について 紹介する。

\section{III. 透水係数におよばす応力の影響}

室内試験では1次元の透水係数を測定すること が主となっているので, 間隙水圧や主応力による 影響量評価を容易に行うことができる。そこで, 著者らが現在までに実施した透水試験結果のうち, 間隙水圧・封圧・最大主応力・中間主応力および 脆性破壊と延性破壊挙動時における透水係数の変 化についての代表的な事例について紹介する。な お, 供試体は直径 $3 \mathrm{~cm}$, 高さ $6 \mathrm{~cm}$ の円柱形もし くは3.4 $\times 3.4 \times 7.0 \mathrm{~cm}$ の角柱形である。透水係数

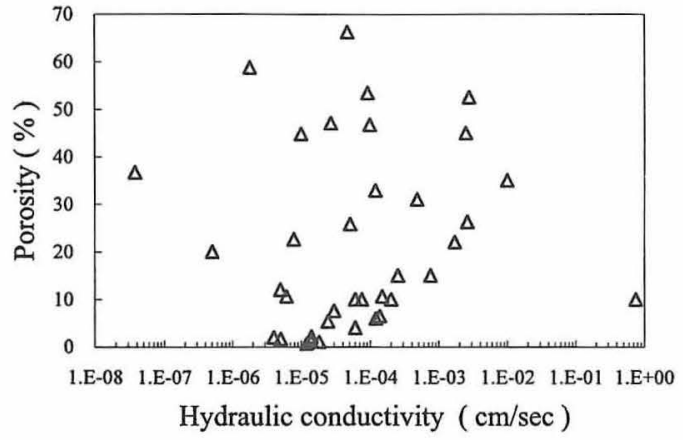

Fig. 2 The relationship between porosity and hydraulic conductivity of rocks (from articles published in Japan)

はいずれの供試体においても長軸（最大主応力） 方向の1次元透水係数である。測定手法は, トラ ンジェントパルス法であり, 飽和状態に扔かれた 岩石供試体の一端から, 間隙水圧をパルス状（設 定間隙水圧の $1 / 20 \sim 1 / 50$ 程度）に与え，このパ ルス压の減衰一時間変化から透水係数を評価する 手法である。この手法の最大のメリットは, 任意 の地下応力条件 (深度, 間隙水圧等) を再現でき る点にある。用いた岩種は白浜砂岩と稲田花崗岩 である。白浜砂岩は南紀白浜の均質な中粒砂岩で あり, 有効間隙率は約 $11 \%$ である。稲田花崗岩は 茨城県産の花崗岩であり, 有効間隙率は約 $0.6 \%$ である。

\section{1. 間隙水圧による影響}

透水係数に及ぼす間隙水圧のみの影響を調べた 事例は極めて少ない。そこで, 白浜砂岩を供試体 として封圧 $30 \mathrm{MPa}$ 一定の条件で, 間隙水圧を最 大 $20 \mathrm{MPa}$ まで載荷したときの透水係数の变化を Fig. 3 に示す。透水係数は間隙水圧の増加ととも に増加している。

最近の研究事例では, 透水係数測定の際の間隙 水圧の増加あるいは減少速度に注意しないと, 供 試体中の水位分布を大きく変化させ, 結果として 動水勾配分布を大きく変化させることなどが指摘 されている(張ほか, 1999)。間隙水圧の影響を 検討する場合には, 間隙水圧の負荷・除荷速度を 


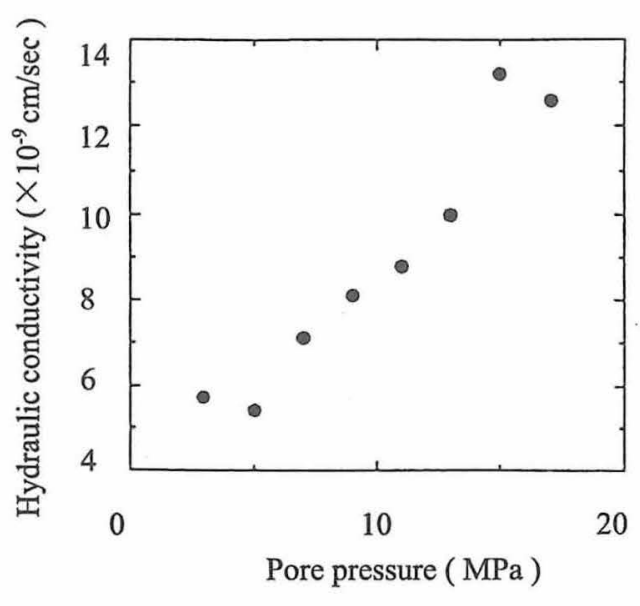

Fig. 3 Effect of pore pressure on hydraulic conductivity (Shirahama sand stone)

小さくし，しかも動水勾配が一定となるよう十分 時間を置きながら実験をしなければならない。

\section{2. 封圧による影響}

透水係数に及ほす封圧の影響については多くの 報告事例がある。定性的には封圧の增加とともに 透水係数は小さくなることが報告されている。 Fig. 4 は白浜砂岩における間隙水圧を $20 \mathrm{MPa}$ 定としたときの透水係数の変化を 4 個の異なる供 試体を用いて測定したときの結果を示している。 全体的な傾向としては, 封圧の増加に伴い透水係 数は低下していることが認められる。一般的には, 封圧が小さなときほど大きな透水係数の減少をも たらすが, 封圧が徐々に大きくなるにつれ透水係 数の減少の度合いが小さくなり, ある程度以上の 封压にいたると透水係数はもはや減少しなくなる。 Fig.4では透水係数の变化が急激に変わる点の応 力を, それぞれ $\mathrm{A}, \mathrm{B}$ 記しているが, この点の 封圧は岩石の変形特性, 特に内部微視的構造の変 化と深く関連している。これについては李ほか （1998）で詳しく述べられている。

\section{3. 軸差応力による影響}

Fig. 5 は稲田花崗岩の潜在割れ目面毎 (注 2) の透水係数に及ぼす軸差応力の影響を示している。

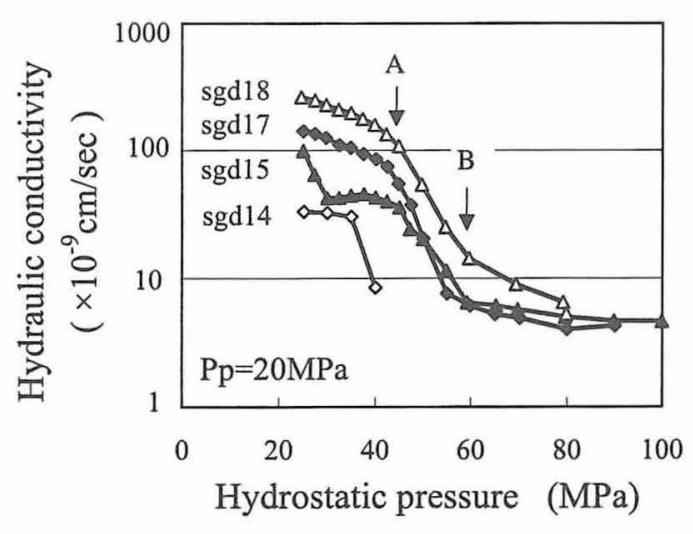

Fig. 4 Effect of confining pressure on hydraulic conductivity (Shirahama sand stone)

封圧 $(\mathrm{Pc})$ および間隙水圧 $(\mathrm{Pp})$ は $20 \mathrm{MPa}$ と 12 $\mathrm{MPa}$ 一定である。横軸は軸差応力を示している が, リフト, グレイン, ハードウェイ面ごとに最 大の軸差応力, すなわち破壞強度が異なることが わかる。また, 透水係数はいずれの面においても 軸差応力の増加とともに減少するが, 体積歪みが 線型状態から非線型状態へと変化する時の応力レ ベルから, ほほ増加に転じ, 最終的な破断面形成 時には大きく増加していることが認められる。こ のように透水係数が軸差応力の影響を強く受ける ことは, マイクロクラックの発生や連結, そして 全体的な量に大きく依存していることが推定でき る。すなわち, 軸差応力の初期の載荷では既存マ イクロクラックの閉鎖や孤立化などにより透水係 数が減少し, 破壞強度の半分程度より大きな軸差 応力下では新たなマイクロクラックの発生や連結 が進み, 透水係数が大きくなったものと考えられ る。最大強度以上では供試体の分離が起こり, 透 水係数は 1 桁以上急激に大きくなる。こうして, 稲田花崗岩供試体はインタクトな状態から破壞後 にいたるまで透水係数は3桁以上にわたって変化 することが確認された。なお，この時には変形特 性も同時に計測されており，体積歪み特性もFig. 6 にその一例を示すように把握されている。した がって, 変形に伴い供試体の貯留特性も大きく変 化していることになる。このような供試体の変形 

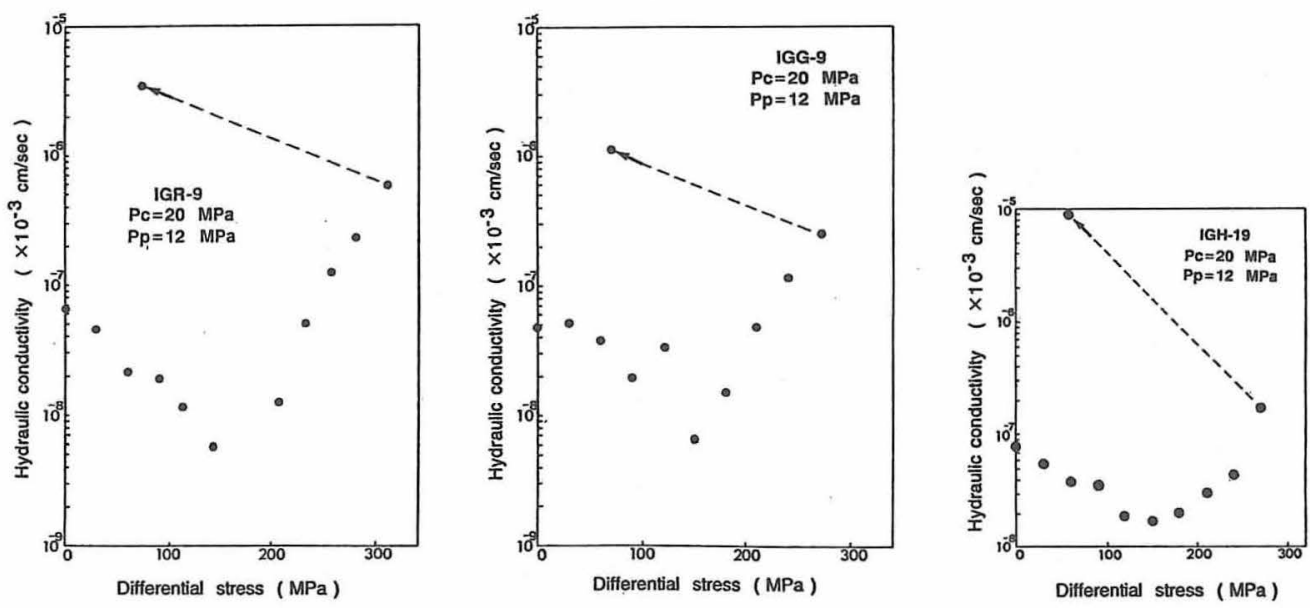

Fig. 5 Hydraulic conductivity of Inada granite as a function of axial differential stress
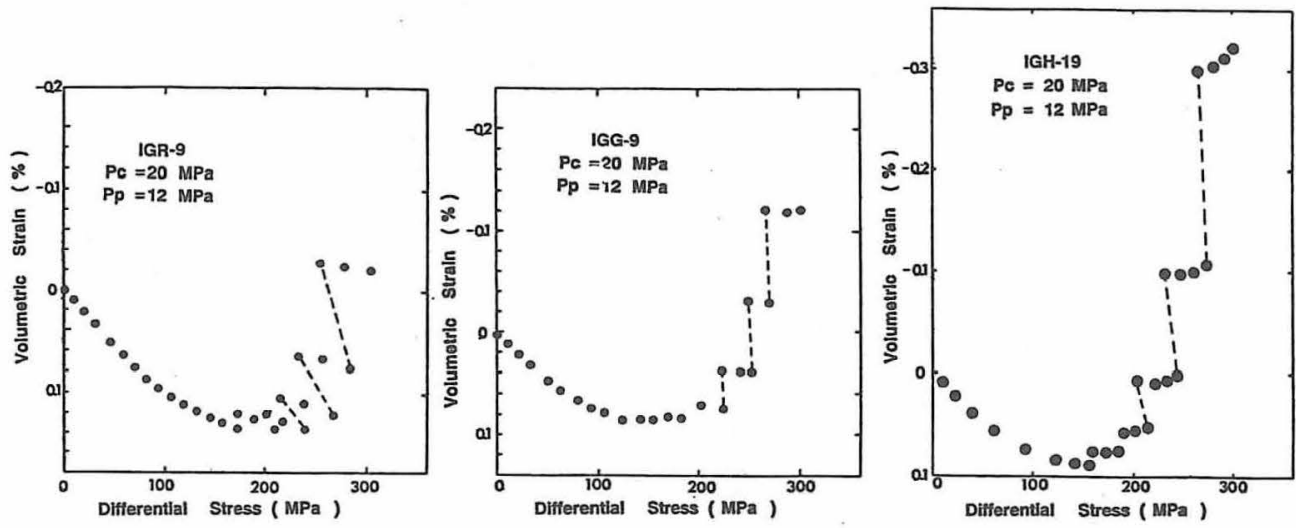

Fig. 6 Volumetric strain vs. axial differential stress

を伴うような場合の透水特性の評価には貯留特性 の評価と併せた議論が必要であり, 貯留特性の評 価なしに，透水特性のみを評価することは誤った 定量評価につながる危険性がある。

Fig. 7 は白浜砂岩の封圧が7 $\mathrm{MPa}$, 間隙水圧が $3 \mathrm{MPa}$ の場合の結果である。稲田花崗岩と異なり, 軸差応力の全般をとおして透水係数の変化は小さ く，破壊強度にいたる直前にわずかに増加するだ けである。破壊後の供試体には封圧油が入り込み, 透水係数は測定不能となっている。稲田花崗岩と の比較から, 透水係数を応力によって生じるマイ クロクラックの連結性の指標とみなすと, 白浜砂 岩は稲田花崗岩よりマイクロクラックの連結性が 恶い,もしくは連結しても流体移動には寄与しな い程度であることが示唆される。

\section{4.中間主応力による影響}

Fig. 8 は最小主応力が $10 \mathrm{MPa}$ および $15 \mathrm{MPa} の$ ときの透水係数に及ぼす中間主応力の影響を示し たものである(高橋ほか，1993）。真三軸試験に おける応力状態は最小主応力を固定し, 中間主応 力と最大主応力を順次増加させながら透水係数を 測定する方法を採用しているので，Fig. 9 のよう な載荷経路と応力值をとることになる。したがっ て, Fig. 8中には最大主応力の值を異なるシンボ ルで示している。透水係数は中間主応力の増加と ともに，いずれの最小主応力・最大主応力におい ても減少することがわかる。ただし，最大主応力 が45MPa以上では中間主応力の影響を受けなく なる。 


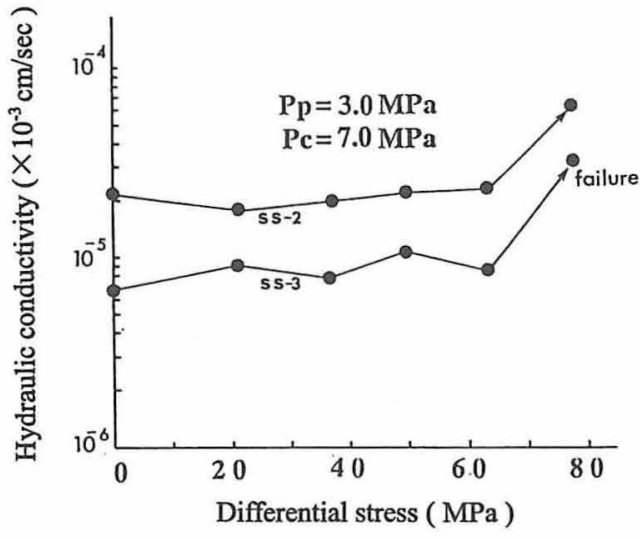

Fig. 7 Hydraulic conductivity of Shirahama sand stone as a function of axial differential stress under constant pore pressure of $3.0 \mathrm{MPa}$ and constant confining pressure of 7.0 $\mathrm{MPa}$

(a)

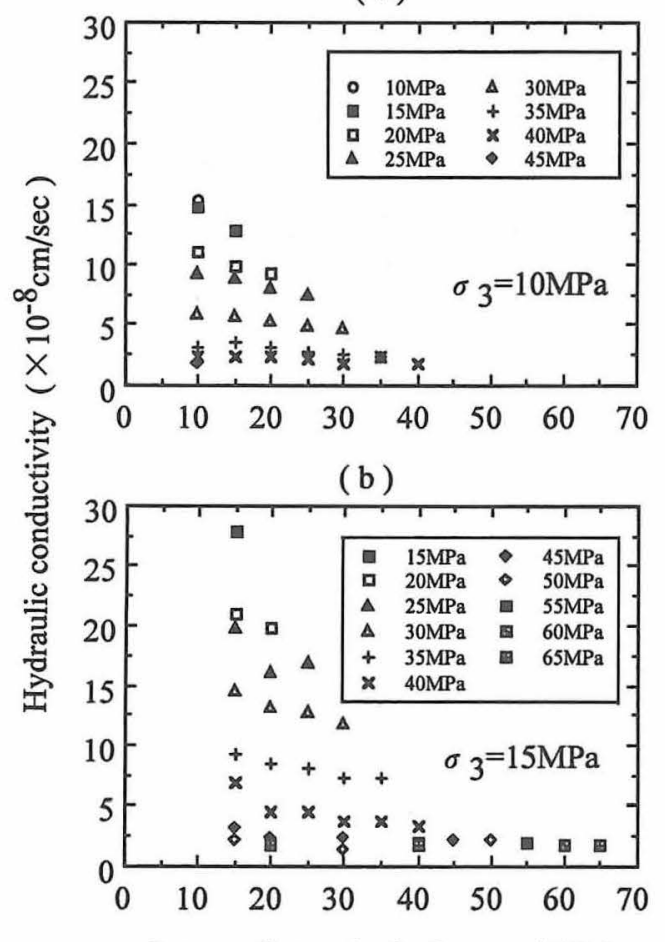

Intermediate principal stress $(\mathrm{MPa})$

Fig. 8 Effect of intermediate principal stress on hydraulic conductivity (a)

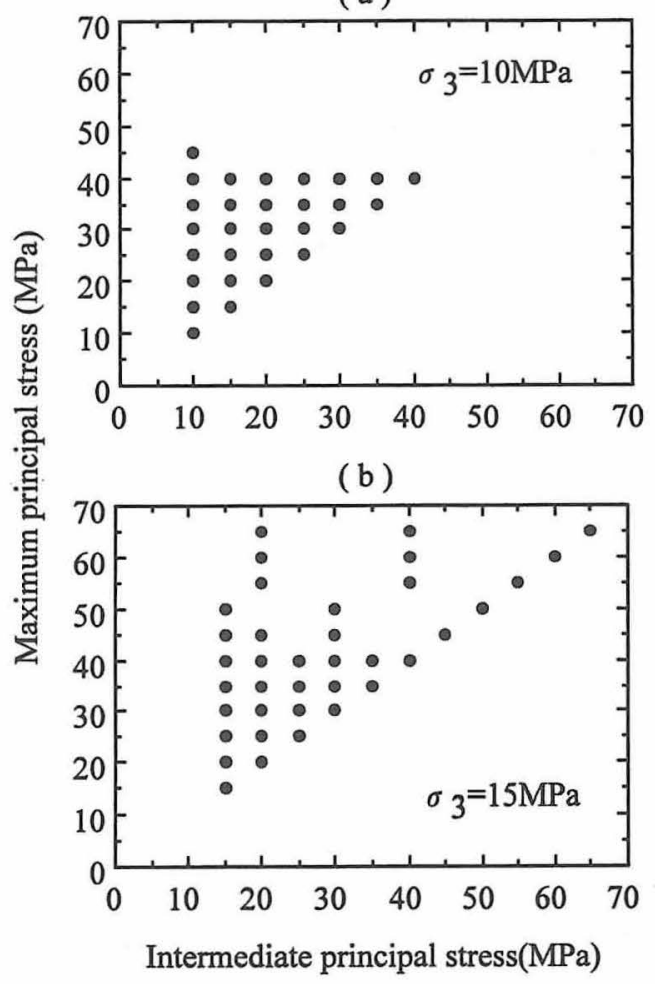

Fig. 9 Stress conditions for the test

\section{5. 脆性破壞および延性破壞挙動による影響}

供試体は白浜砂岩を用いて, 封圧は最大 100 $\mathrm{MPa}$ まで, 間隙水圧は $20 \mathrm{MPa}$ 一定とした応力軸 歪み曲線をFig.10（a）に示す。低封圧域で脆性 挙動を示していたものが, 封圧の増加とともに最 大強度が増加すると同時に応力降下量が少なくな り, 結果として延性状態へと遷移している。供試 体の体積変化は同図（b）に示されるように脆性 領域では圧縮側から膨張側への反転現象が認めら れるが, 封圧の増加とともに延性状態に遷移する につれ体積变化は圧縮側に圧倒的に依存し, 徐荷 後も圧縮が続くことになる。脆性破壊挙動から延 性破壊挙動に至るまでの透水係数の変化は同図 (c)に示されている。封圧 $40 \mathrm{MPa}$ では体積歪み 特性と同じょうに, 透水係数は一旦減少するもの の，体積が澎張側に転じるのと同じく透水係数は 増加している。透水係数の減少から増加への傾向 は量的な違いはあるもののいずれの封圧において 
も当てはまる現象である。白浜砂岩における変形 挙動と透水特性および内部構造との関連について は李ほか (1998) にまとめられている。

\section{$\mathbb{N}$ ． 供試体内の動水勾配の評価について}

数 $\mathrm{cm}$ サイズのコアにおいて, 透水係数が封圧 や間隙水圧等の応力によって大きく変化する事が 確認された。これらは“透水係数” 即ち圧力の変 化の違いとして，実測值からその違いを評価する ことができた。ところが, 供試体内部での水位分 布や動水勾配分布等の評価は, 実測値が得られな いという制約があり, 従来室内透水試験では議論 されていなかった。そこで, 本文では室内透水試 験の精度向上のため, 非定常厳密解を用いた数値 シミュレーションによって, 岩石供試体内部の水 位分布や動水勾配分布を評価したので, その一部 を紹介する。

Brace et al. (1968) は, Westerly 花崗岩の 透水特性を計測するためトランジェントパルス法 を提案した。この装置は円柱形の岩石供試体とそ れに連結した二つの貯留容器からなる (Fig.11参 照)。試験方法は, 岩石供試体に間隙水圧を加之 た状態から，片方の貯留容器に瞬間的に圧力パル スを与える。流体は加圧した貯留容器から徐々に 供試体を通り他方の容器に到達し, 同時に加圧し た容器内の圧力は徐々に減少する。透水係数は供 試体に連結した貯留容器の水圧の経時的変化から 求められる。Braceらが行ったトランジェントパ ルス法の理論解析は, 岩石供試体自身の圧縮によ る貯留を無視したものである。この解析はFig.11 において容器1の圧力P1の厷力減小による以下に 示すような指数関数から得られる。

$P_{l}-P_{f}=H \cdot \frac{V_{d}}{V_{u} V_{d}} \cdot e^{-0 t}$

ここで, $\theta=\left(K A / \gamma_{w} \lambda L\right)\left(1 / V_{u}+1 / V_{d}\right)$

$V_{u}$ と $V_{d}$ はそれぞれ上流及び下流側貯留槽の容 積, $P_{f}$ は圧力の収束値, $H$ は圧力パルスの大き

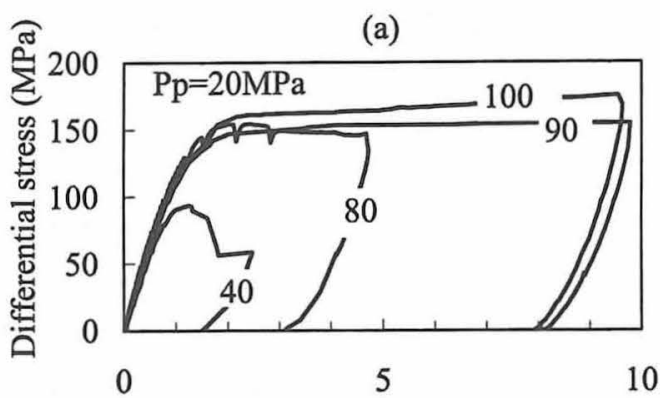

(b)

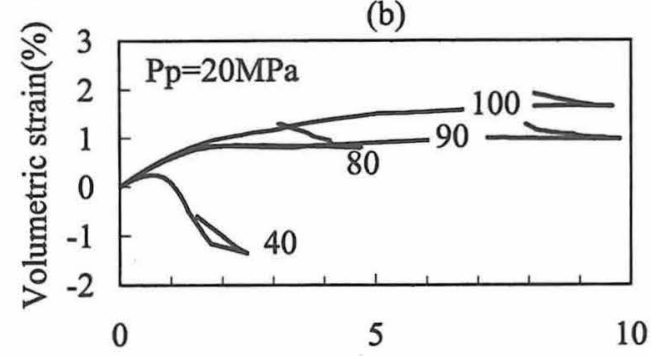

(c)

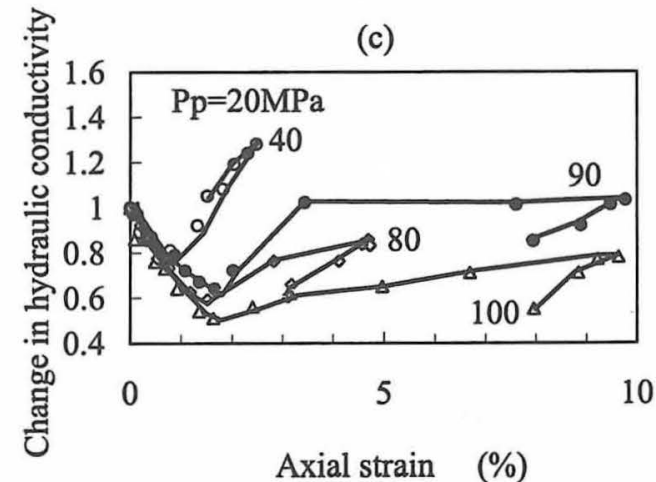

Fig.10 Differential stress, volumetric strain and hydraulic conductivity as a function of axial strain during axial compression under various confining pressures indicated by the figures.For each of the specimens, the pore pressure $(\mathrm{Pp})$ is $20 \mathrm{MPa}$. The initial hydraulic conductivity is taken as 1 .

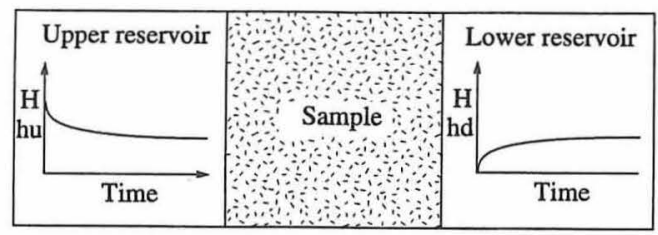

Fig.11 Transient pulse technique. 
さ， $\gamma_{w}$ は流体の比重， $\lambda$ は流体の圧縮率である。 透水係数は試験から得られた指数関数的に減少す る圧力時間曲線 $\left(P_{I}-P_{f}\right)$ の傾き $-\theta$ から式 (3) より算出する。基本的に圧縮貯留性を考慮してい ないこの仮定は，有効間隙率が小さな結晶質岩に とって合理的であるが, 多孔質で圧縮貯留性に富 む堆積岩類の岩種にとっては適当でない。そのた め, Hsieh（1981）らが岩石供試体自身の圧縮貯 留特性を考慮したトランジェントパルス法の厳密 解析理論を導いた。Hsiehらの手法では，上下流 貯留槽の圧力の変化から供試体の透水係数のみな らず，供試体の比貯留率も評価できるようになっ ている。供試体中の水頭分布の経時的変化は次式 で表される一般解より評価できる。

$$
\begin{aligned}
& \frac{h(Z, t)}{H}=\frac{1}{1+\beta+\gamma} \\
& +\sum_{m=1}^{\infty} \frac{\exp \left(-\frac{K t}{L^{2} S_{s}} \phi_{m}^{2}\right)\left[\cos \left(\phi_{m} \frac{Z}{L}\right)-\left(\frac{\gamma \phi_{m}}{\beta}\right) \sin \left(\phi_{m} \frac{Z}{L}\right)\right]}{\left(1+\beta+\gamma-\frac{\gamma \phi_{m}^{2}}{\beta}\right) \cos \phi_{m}-\phi_{m}\left(1+\gamma+\frac{2 \gamma}{\beta}\right) \sin \phi_{m}}
\end{aligned}
$$

ここで,

$$
\zeta=\frac{Z}{L}, \quad \alpha=\frac{K t}{L^{2} S_{s}}, \quad \beta=\frac{S_{\mathrm{s}} A L}{S_{u}}, \quad \gamma=\frac{S_{d}}{S_{u}}
$$

また, $S_{u}$ 及び $S_{d}$ はそれぞれ上下流貯留槽の貯留 率, $\phi_{m}$ は次の方程式の根である。

$$
\tan \phi=\frac{(\gamma+1) \phi}{\gamma \phi^{2} / \beta-\beta}
$$

式（4）を更に $Z$ に対して微分すれば，供試体中の 動水勾配は次式により求められる。

$$
\begin{aligned}
& \frac{i(Z, t)}{H}=2 \sum_{m=1}^{\infty} \frac{\phi_{m}}{L} \\
& \frac{\exp \left(\frac{-K t}{L^{2} S_{s}} \phi_{m}^{2}\right)\left[\sin \left(\phi_{m} \frac{Z}{L}\right)-\left(\frac{\gamma \phi_{m}}{\beta}\right) \cos \left(\phi_{m} \frac{Z}{L}\right)\right]}{\left(1+\beta+\gamma-\frac{\gamma \phi_{m}^{2}}{\beta}\right) \cos \phi_{m}-\phi_{m}\left(1+\gamma+\frac{2 \gamma}{\beta}\right) \sin \phi_{m}}
\end{aligned}
$$

式(4)及び(6)を用いてシミュレーションしたト ランジェントパルス透水試験中の供試体内部の水 位分布や動水勾配の一例をFig. 12，13に示す。

仮定した供試体は直径 $5 \mathrm{~cm}$, 高さ $10 \mathrm{~cm}$ の円柱 状である。ここでは, 透水係数が $K=10^{-9} \mathrm{~cm} / \mathrm{sec}$ (Case1) と $10^{-11} \mathrm{~cm} / \mathrm{sec}$ (Case2) の場合につい て, 三次元貯留係数は $5 \times 10^{-8} \mathrm{l} / \mathrm{cm}$ でシミュレー ションした結果について検討する。なお, 上流側, 下流側の圧力貯留槽はそれぞれ $500 \mathrm{ml}$ とした。 Fig. 12,13は透水係数が $10^{-9}, 10^{-11} \mathrm{~cm} / \mathrm{sec}$ の場 合の結果である。水頭分布, 動水勾配分布ともパ ルス圧で正規化した值で示した。両者とも，上流 側 $(1.0 \mathrm{~L})$ では急激な圧力水頭の増加の後に, 時間経過とともに減少し，一定值に漸近している。 上流側に近い $0.9 \mathrm{~L}$ から $0.6 \mathrm{~L}$ までは急激な増加の 後極大值を示しながら一定值に収束している。一 方，下流側に近い部分では時間経過と共に増加し， 一定値に漸近している。動水勾配については，変 水位法と同じように場所ごとに相当複雑な変化を 示しており，透水係数によるその傾向の違いは見 いだせない。変水位法と合わせ, トランジェント パルス法は複雑な水頭分布と動水勾配分布を示す ことに留意しなければならない。

Wang（1993）らはトランジェントパルス透水 試験における透水係数及び比貯留率の最適評価は 圧力パルスが迅速に低下する部分の結果を用いて 行うことを提案しているが, その時供試体中に発 生する動水勾配は比較的大きい。また, 動水勾配 の值も急激に変化している。そのため, Wangら の提案の通りに求めた供試体の水理学的常数の信 頼性には疑問がある。実際の現場に近い動水勾配 のもとで透水特性を評価するためには, 圧力パル スをできるだけ小さくする必要がある。従って， 透水試験開始直後の動水勾配の極めて高い状態の 計測結果を利用しない方が良い。

\section{V. をとめ}

岩石の透水係数がおおよそどの程度の範囲に分 布するかを調べた。その結果 $10^{-11}-10^{\circ} \mathrm{cm} / \mathrm{sec}$ 


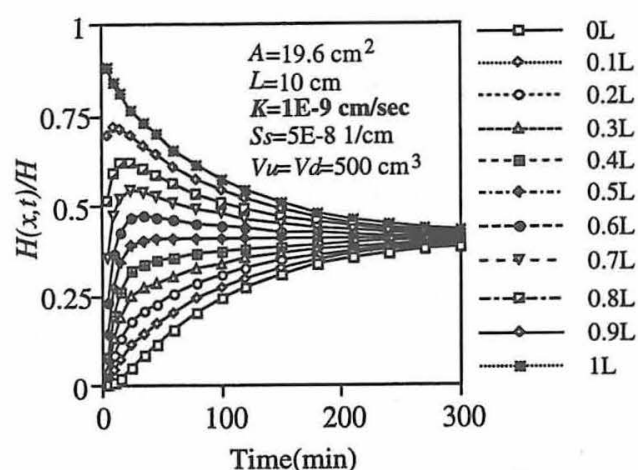

a) Hydraulic head

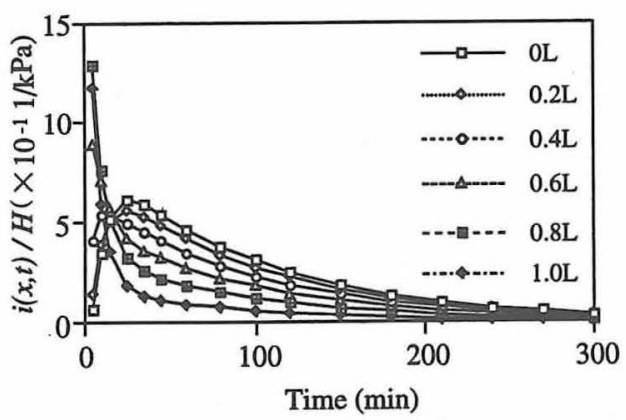

b) Hydraulic gradient

Fig. 12 Simulated hydraulic head and hydraulic gradient distributions within the specimen during the transient pulse test for case 1 .

という広い範囲に分布することがわかった。透水 係数の測定手法, 特に $10^{-12} \mathrm{~cm} / \mathrm{sec}$ という小さな 值を測定する場合にはトランジェントパルス法や フローポンプ法を用いなければならない。トラン ジェントパルス法を用いて白浜砂岩や稲田花崗岩 の各種応力条件（間隙水圧, 封圧, 軸差応力, 中 間主応力, 脆性 ·延性変形挙動) 下での代表的な 結果について整理した。これらと透水試験におけ る測定中の供試体内の水位分布や動水勾配分布に ついて数值シミュレーションを行い, 特に動水勾 配が実験の初期に極めて複雑になることを確認し た。コアサイズの透水係数を精度良く求めるため には, 供試体内の動水勾配を極力小さくする必要 がある。この観点からすると, トランジェントパ ルス法ではパルス圧を小さくする事, フローポン プ法では流量を小さくする事が必要である。いず

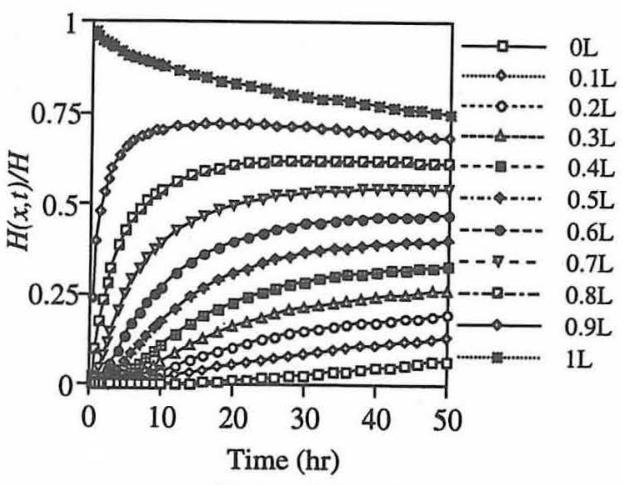

a) Hydraulic head

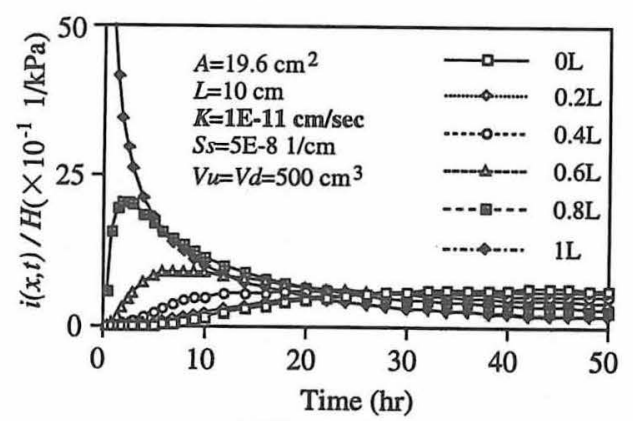

b) Hydraulic gradient

Fig. 13 Simulated hydraulic head and hydraulic gradient distributions within the specimen during the transient pulse test for case 2 .

れの条件下においても，解析に耐えられるデータ を得ようとすると, 装置自体の温度変化への対策 や剛性を高くする等の工夫が必要となる。

\section{脚 注}

注 1 [permeability]という単語は, 日本語で は様々な分野で用いられている。一例を示すと， 浸水率 (船舶, 造船船体), 浸透性 (化学, 農 学, 機械設計), 浸透率 (鉱山, 機械, 石油), 通気率 (化学), 透過性 (動物, 化学, 分光, プラスティック, 原子力, 農学, 環境工学, 植 物), 透湿率 (建築材料), 透磁率 (採鉱冶金, 計測, 化学, 電気), その他, 透水係数, 透水 度, 透水性など。

注 2 一般に花崗岩には互いに直交する3つの割 
机易い面が存在する。採石場ではこれらの面の 存在は昔からよく知られており，地域によって 多少呼び方は違うが, 割れ易い面から順番に 「目」(1番)，「2番」，「重ね」(しわ)，等と呼 ばれていることが多い。これらに対応する英語の 名称は，それぞれRift Plane, Grain Plane, Hardway Plane, である。ここでは以下, 英 語の呼び方に従うこととする。Rift面とGrain 面を特徴づけるものは，これらの面に沿う方向 に選択的に配向された潜在クラックである。こ れらのクラックは石英内に多く存在するが, R ift面に沿うクラックの方がGrain面に沿うク ラックよりも長く, 密度も高い。一方, Hard way面は多くの場合，液体包有物や裂開などに よって特徴づけられる。液体包有物は長石内に 多く存在する。このように各面内に存在するク ラックの選択的な配向により，P波速度や圧裂 引張強度などのクラックの存在に敏感な物理量 に著しい異方性が生じると考えられている。こ れら花崗岩の力学的異方性や潜在クラックの形 態などは，工藤ほか $(1986 a, b)$ 等によって詳 しく研究されている。

\section{文 献}

工藤洋三・橋本堅一・佐野 修・中川浩二 (1986 a) : 石工の経験則と花崗岩の力学的性質.土と 基礎，34（8），47-51.

工藤洋三・橋本堅一・佐野 修 $\cdot$ 中川浩二 $(1986$ b) : 花崗岩の力学的異方性と岩石組織欠陥の 分布. 土木学会論文集, 370, 189-198. 小鯛桂一 (1985) : 粒状堆積物の透水性, 間隙率 と地質年代の関係. 土と基礎，33（3），61-64. 高橋 学・杉田 裕・薜 自求・大西康智・石島 洋二 (1993)：白浜砂岩の透水特性に及ぼす各 主応力の影響についてーダイラタンシー以前の 応力状態の場合一. 資源と素材, 109, 802-808. 高橋 学·張 銘·林 為人 - 西山 哲·李 小 春（1998）: 室内透水試験における供試体中の
水頭分布，動水勾配，貯留係数について，資源 と素材，114，888-894.

張 銘- 高橋 学・江崎哲郎 - 林 為人 - 竹田幹 郎（1999）: 室内三軸及び透水試験における間 隙水圧の加圧過程について. 北海道応用地学合 同研究会論文集, 10, 73-78.

柳澤孝一・古屋和夫 · 大澤英昭 - 若松尚則 - 梅田 浩司（1992）：我が国における地盤の透水性に 関する調査・研究（その1）－各岩種における 透水係数の収集・解析一. PNC TN 7410 92015.

李 小春・高橋 学・張 銘 (1998) : 白浜砂岩 の延性挙動と透水特性との関連について. 第10 回岩の力学国内シンポジウム講演論文集, 707712 .

Brace, W. F., Walsh, J. B. and Frangos, W. T. (1968) : Permeability of granite under high pressure. J. Geophys. Res., 73, 2225-2236.

Hsieh, P. A., Tracy, J. V., Neuzil, G. E., Bredehoeft, J. D. and Silliman, S. E. (1981) : A transient laboratory method for determining the hydraulic properties of 'tight' rocks I-, Theory. Int. J. Rock Mech. Min. Sci. \& Geomech. Abstr., 18, 245-252.

Touloukian, Y. S., Judd, W. R. and Roy, R. F. (1989) : Physical Properties of Rocks and Minerals. CINDAS Data Series on Materials Properties, II (2), 63-76.

Wang, H. F. and Hart, D. J. (1993) : Experimental error for permeability and specific storage from pulse decay measurements. Int. J. Rock Mech. Min. Sci. \& Geomech. Abstr., 30, 11731176.

（受付：1999年 5 月 8 日）

(受理 : 1999年 9 月 2 日)

この論文に対する「討論」を1999年 5 月 31 日ま で受付けます。 